Ariani, Bawono/ 2018

\title{
PENGARUH UKURAN DAN UMUR PERUSAHAAN TERHADAP AUDIT REPORT LAG DENGAN PROFITABILITAS DAN SOLVABILITAS SEBAGAI VARIABEL MODERATING
}

\author{
Kurnia Rina Ariani ${ }^{1}$ \\ *Program Studi Akuntansi, Fakultas Ekonomi dan Bisnis, UniversitasMuhammadiyah Surakarta \\ kra123@ums.ac.id ${ }^{l}$ \\ Andy Dwi Bayu Bawono ${ }^{2}$ \\ * Program Studi Akuntansi, Fakultas Ekonomi dan Bisnis, UniversitasMuhammadiyah Surakarta \\ *andy.bawono@ums.ac.id ${ }^{2}$
}

\begin{abstract}
Abstrak
This research aims to analyze the effect of companies ages and size to audit report lag with profitability and solvability as a moderating variable in manufacturing companies listed in Indonesian Stock Exchange for year end from 2015-2016. Moderating variable used in this research to know whether profitability and solvability can moderate the relationship between companies ages and size to audit report lag. Using Moderated Regression Analysis this research can provide empirical evidence that (i) companies ages has no effect on audit report lag, (ii) companies size has negative effect on audit report lag (iii) profitability and solvability cannot moderate the relationship between companies ages and size to audit report lag.
\end{abstract}

Keywords: audit report lag, companies size, companies ages, profitability, solvability

\section{PENDAHULUAN}

Proses akhir dalam suatu siklus akuntansi adalah dihasilkannya laporan keuangan sebagai dasar dalam pengambilan keputusan yang didalanya terdapat informasi mengenai pengukuran dan penilaian kinerja sebuah perusahaan meliputi posisi keuangan, kinerja keuangan dan arus kas entitas. Banyak pihak yang berkepentingan dengan informasi yang terdapat dalam laporan keuangan baik itu pihak internal maupun eksternal perusahaan [1].

Perusahaan yang telah terdaftar di Bursa Efek Indonesia wajib menyusun dan menyajikan laporan keuangan kepada publik sesuai standar akuntasi yang secara umum diterima sebagai aturan baku dan didukung oleh sanksi-sanksi untuk setiap ketidakpatuhan untuk dijadikan sebagai pedoman pokok [2]. Pemenuhan Standar Akuntansi Keuangan (SAK) oleh auditor akan berdampak pada kualitas hasil audit dan lamanya pelaporan hasil audit. Hasil audit atas laporan keuangan perusahaan publik mempunyai konsekuensi dan tanggung jawab yang besar bagi auditor. Tanggung jawab ini dapat dilihat dalam pemenuhan tugas auditor untuk dapat menyampakan laporan auditnya secara tepat waktu sesuai yang disyaratkan oleh Otoritas Jasa Keuangan (OJK) selambat-lambatnya empat bulan setelah laporan keuangan tahunan. Adapun pemeriksaan laporan keuangan oleh auditor independen dilakukan untuk menilai kewajaran penyajian atas laporan keuangan.

Audit report lag atau lamanya waktu penyelesaian audit yang dilakukan oleh seorang auditor dapat diidentifikasi dengan cara menghitung antara tanggal laporan keuangan sampai dengan tanggal laporan auditor independen. Semakin panjang audit report lag dapat memberikan dampak negatif bagi pengguna laporan keuangan [3].

Semakin panjang rentang waktu antara tutup buku laporan keuangan dan penyampaian laporan keuangan ke publik maka akan semakin tinggi kemungkinan bahwa informasi tersebut akan dibocorkan ke beberapa investor [4]. [5] menjelaskan ketepatwaktuan informasi mengandung pengertian bahwa informasi tersedia sebelum kehilangan kemampuannya untuk mempengaruhi atau membuat perbedaan dalam keputusan. Sehingga dapat disimpulkan informasi yang memiliki prediksi tinggi menjadi tidak relevan apabila tidak tersedia pada saat dibutuhkan.

Terkait dengan audit report lag ada beberapa faktor yang mempengaruhi terjadinya audit report lag 
antara lain ukuran perusahaan, umur perusahaan, perubahan kebijakan SAK, profitabiltas, solvabilitas dan kompleksitas perusahaan.

Umur dan ukuran perusahaan diperkirakan dapat mempengaruhi audit report lag, karena perusahaan yang memiliki umur lebih lama dinilai lebih berhatihati dan lebih terbiasa untuk melaporkan laporan keuangan dengan tepat waktu. Hasil penelitian yang dilakukan oleh [6] menyatakan bahwa umur dan ukuran perusahaan berpengaruh terhadap audit report lag. Hal ini dapat diartikan bahwa perusahaan yang memiliki umur lebih tua dan kepemilikan aset yang besar dinilai lebih mampu dalam mengumpulkan, memproses, dan menghasilkan informasi yang diperlukan dalam menyusun dan menyajikan laporan keuangan karena telah memiliki pengalaman yang cukup banyak dalam hal tersebut sehingga mempermudah auditor dalam melaksanakan tugasnya tepat waktu.

Dalam beberapa penelitian kinerja keuangan suatu perusahaan dapat memperpendek lamanya audit report lag hal ini dapat mengindikasikan bahwa perusahaan yang memiliki pengalaman yang sudah lama dan kemampuan finansial yang besar akan mempunyai kesempatan untuk dapat menghasilkan kinerja keuangan yang baik dan segera menerbitkan laporan keuangan terkait reputasinya dimata investor.

Penelitian ini menggunakan dua variable independen yaitu ukuran dan umur perusahaan untuk mengetahui pengaruhnya terhadap audit report lag. Dengan menambahkan profitabilitas dan solvabilitas sebagai variable moderating untuk menguji apakah variable moderating tersebut dapat memperkuat atau memperlemah hubungan antara variable independen dan variable dependen.

\section{KAJIAN PUSTAKA DAN PENGEMBANGAN HIPOTESIS}

\section{Teori Kepatuhan (Compliance Theory)}

Kepatuhan adalah mengikuti suatu spesifikasi, standar atau hukum yang telah diatur dengan jelas yang biasanya diterbitkan oleh lembaga atau organisasi yang berwenang dalam suatu bidang tertentu.

Terdapat dua perspektif dasar dalam literature sosiologi mengenai kepatuhan dalam hokum, yang disebut instrumental dan normatif [7] Perspektif instrumental mengasumsikan individu secara utuh didorong oleh kepentingan pribadi dan tanggapan terhadap perubahan-perubahan dalam tangible, insentif, dan penalti yang berhubungan dengan perilaku. Perspektif normatif berhubungan dengan apa yang orang anggap sebagai moral dan berlawanan dengan kepentingan pribadi mereka. Seorang individu cenderung mematuhi hukum yang mereka anggap sesuai dan konsisten dengan norma-norma internal mereka.

Berdasarkan perspektif normatif teori kepatuhan ini dapat diterapkan di bidang akuntansi, sehubungan dengan ketepatan waktu pelaporan keuangan oleh perusahaan- perusahaan yang listed di Bursa Efek Indonesia yang telah diatur dalam Surat Keputusan Ketua OJK Nomor: Kep-36/PM/2003 tentang kewajiban penyampaian laporan keuangan secara berkala. Dapat disimpulkan kepatuhan emiten dalam melaporkan pelaporan keuangan merupakan suatu hal yang mutlak dalam memenuhi kepatuhan terhadap prinsip pengungkapan informasi yang tepat waktu.

\section{Teori Kontingensi}

Teori kontingensi teori situasional [8] mengemukakan kepemimpinan tergantung pada situasi atau dengan kata lain kontingensi merupakan ketidakpastian yang tidak dapat diterapkan secara universal. Teori ini mempunyai postulat bahwa efektivitas suatu organisasi dalam mengatasi ketidakpastian lingkungan merupakan unsur-unsur dari berbagai subsitem yang dirancang untuk memenuhi tuntutan lingkungan yang saling berhubungan.

Dengan mengacu kepada teori kontingensi maka terdapat variable moderasi yang memperkuat atau memperlemah variable independen terhadap variable dependen yang berkaitan dengan audit report lag.

\section{Pengaruh Ukuran Perusahaan Terhadap Audit Report Lag}

Ukuran perusahaan merupakan besar kecil suatu perusahaan dengan berbagai cara antara lain dinyatakan dengan jumlah kekayaan (total assets), nilai pasar saham, jumlah penjualan dalam satu tahun periode penjualan, jumlah tenaga kerja, dan total nilai buku tetap perusahaan [9] 
Ukuran perusahaan merupakan fungsi dari kecepatan publikasi laporan keuangan karena perusahaan dengan ukuran besar terdapat internal control yang baik sehingga mendorong auditornya menyelesaikan proses audit secara tepat waktu [10], [11], [6], [12], [13], [14], [15], [16].

$H_{1}$ : Ukuran perusahaan berpengaruh terhadap audit report lag

\section{Pengaruh Umur Perusahaan Terhadap Audit Report Lag}

Menurut [6] umur perusahaan adalah lamanya waktu hidup suatu perusahaan yang menunjukkan bahwa perusahaan tetap eksis, mampu bersaing dalam dunia usaha dan mampu mempertahankan kesinambungan usahanya serta merupakan bagian dari dokumentasi yang menunjukan tujuan dari perusahaan tersebut.

Perusahaan yang telah lama berdiri mempunyai kemungkinan untuk mempersingkat audit report lag. Hal ini dikarenakan perusahaan yang telah lama berdiri mempunyai pengalaman yang lebih banyak dalam tata kelola SPI perusahaan dibandingkan perusahaan yang baru berdiri. Perusahaan yang mempunyai tata kelola dan SPI yang baik maka perusahaan akan mampu menyediakan bukti yang handal dalam proses audit perusahaan sehingga mempercepat atau mempersingkat audit report lag [6], [12], [17], [18].

$\mathrm{H}_{2}$ : Umur perusahaan berpengaruh terhadap audit report lag

\section{Pengaruh Ukuran Perusahaan terhadap Audit Report Lag yang Dimoderasi oleh Profitabiltas}

Perusahaan berkeuangan baik dicerminkan dengan besarnya total aset yang dimiliki. Hal ini memungkinkan suatu perusahaan untuk dapat mengembangkan pengelolaan manajemen yang baik pula dikarenakan ketersidaan sumber daya finansial maupun non finansial yang melimpah yang pada akhirnya dapat meningkatkan kemampuan perusahaan untuk menghasilkan laba dalam jangka panjang.

Perusahaan besar dengan profit yang tinggi memiliki biaya politik yang besar dibandingkan dengan perusahaan yang kecil. Perusahaan besar dan memiliki profit yang besar akan lebih mampu untuk merekrut auditor yang bereputasi baik guna mengaudit laporan keuanga secara tepat waktu untuk menjamin ketersediaan informasi bagi investor [19]

$\mathrm{H}_{3}$ : Profitabilitas memoderasi hubungan antara ukuran perusahaan dengan audit report lag

\section{Pengaruh Umur Perusahaan terhadap Audit} Report Lag yang Dimoderasi oleh Profitabiltas

Profitabilitas merupakan indikator kinerja oleh manajemen dalam pengelolaan kekayaan yang dimiliki perusahaan yang dapat ditunjukkan oleh laba yang dihasilkan. Profitabilitas dapat menunjukkan tingkat kinerja dan efisiensi perusahaan dalam menghasilkan keuntungan bagi pemegang saham.

Semakin lama berdirinya suatu perusahaan mengindikasikan perusahaan tersebut mampu bertahan dalam berbagai kondisi pasar yang berubah-ubah dengan mengandalkan kemampuannya untuk menghasilkan laba yang maksimal.

Profitabilitas menunjukkan tingkat keberhasilan perusahaan dalam memperoleh keuntungan. Tingkat profitabilitas yang rendah akan berpengaruh terhadap lamanya audit report lag. Hal tersebut berkaitan dengan akibat yang dapat ditimbulkan pasar terhadap pengumuman rugi oleh perusahaan. Perusahaan yang dapat menghasilkan laba atau keutungan akan cenderung mengalami audit report lag yang lebih pendek, sehingga perusahaan memiliki good news yang segera dilaporkan dan disampaikan kepada pihak yang berkepentingan dan investor [20], [21].

\section{$\mathrm{H}_{4} \quad$ : Profitabilitas memoderasi} hubungan antara umur perusahaan dengan audit report lag.

\section{Pengaruh Ukuran Perusahaan terhadap Audit Report Lag yang Dimoderasi oleh Solvabilitas}

Perusahaan yang memiliki ukuran yang besar dinilai mampu menghasilkan laba lebih banyak sehingga kemampuan perusahaan dalam membayar kewajiban keuangannya lebih cepat. Hal ini memungkinkan untuk mempermudah kerja auditor untuk mengaudit laporan keuangan tepat waktu dan mempercepat publikasi laporan keuangan tersebut. Kurang orang 
$H_{5}$ : Solvabilitas memoderasi hubungan antara umur perusahaan dengan audit report lag

\section{Pengaruh Umur Perusahaan terhadap Audit Report Lag yang Dimoderasi oleh Solvabilitas}

Solvabilitas adalah kemampuan perusahaan untuk memenuhi seluruh kewajiban finansialnya pada saat perusahaan tersebut dilikuidasi [17]. Solvabilitas dapat pula diartikan sebagai perbandingan antara jumlah hutang dengan jumlah ekuitas yang dimiliki perusahaan.

Perusahaan yang sudah berpengalaman atau mempunyai umur yang panjang dianggap mampu untuk mepertahankan keberadaan atau eksistensi dengan menjaga proporsi utang jangka panjang dibandingkan dengan ekuitasnnya pada level yang baik.

Tingkat solvabilitas perusahaan yang tinggi akan membuat auditor lebih berhati-hati untuk melakukan auditnya, karena hal ini dapat memicu resiko kerugian dari perusahaan ayng diaudit, sehingga menyebabkan audit report lag semakin lama.

$H_{6}$ : Solvabilitas memoderasi hubungan antara ukuran perusahaan dengan audit report lag

\section{METODE PENELITIAN}

\section{Populasi dan Sample}

Populasi yang digunakan dalam penelitian ini adalah seluruh perusahaan manufaktur yang terdaftar dalam Bursa Efek Indonesia (BEI) periode 2015-2016. Pemilihan sampel dilakukan dengan menggunakan metode purposive sampling. Kriteria yang digunakan yaitu perusahaan mengeluarkan laporan keuangannya berturut-turut dari tahun 2015-2016 dan menggunakan mata uang rupiah dalam laporan keuangannya.

\section{Definisi Operasional dan Pengukuran Variabel}

\section{Variabel Dependen}

Variabel dependen yang digunakan dalam penelitian ini adalah audit report lag yang diukur berdasarkan lamanya waktu penyelesaian audit dari tanggal penutupan buku per 31 Desember hingga tanggal ditandatanganinya laporan keuangan oleh auditor independen.

\author{
Variabel Independen \\ a. Ukuran Perusahaan \\ Ukuran perusahaan adalah suatu ukuran yang
} menunjukkan besar kecilnya suatu perusahaan yang ditandai dengan beberapa ukuran antara lain total penjualan, total aset, $\log$ size, jumlah pegawai, nilai pasar perusahaan, dan nilai buku perusahaan. Dalam penelitian ini menggunakan $\log$ total aset sebagai pengukuran.

b. Umur Perusahaan

Umur perusahaan adalah lamanya perusahaan tersebut telah beroperasi. Umur perusahaan dihitung dari tanggal perusahaan itu berdiri sampai dengan saat perusahaan melakukan tutup buku.

\section{Variabel Moderating}

a. Profitabilitas

Profitabilitas adalah kemampuan perusahaan untuk memperoleh laba semaksimal mungkinDalam penelitian ini, profitabilitas diukur menggunakan Return On Assets (ROA) yang dapat dihitung berdasarkan laba bersih dibagi dengan total aktiva.

b. Solvabilitas

Solvabilitas merupakan rasio yang mengukur kemampuan perusahaan dalam membayar seluruh kewajibannya baik jangka pendek maupun jangka panjang. Tingkat solvabilitas diukur dari total kewajiban dibagi dengan total ekuitas. Rasio solvabilitas atau Debt to Equity Ratio (DER) menunjukkan seberapa besar kemampuan perusahaan dalam memenuhi kewajibannya kepada kreditur.

\section{Pengujian Hipotesis}

a. Analisis Regresi Berganda

Dalam penelitian ini analisis linear berganda digunakan untuk mengetahui ketergantungan satu variabel terikat hanya pada dua variabel bebas dengan atau tanpa variabel moderator, serta untuk mengetahui ketergantungan suatu variabel terikat pada variabelvariabel bebas. Teknik analisis ini digunakan untuk mengetahui pengaruh ukuran perusahaan dan umur perusahaan pada audit report lag.

$$
\begin{gathered}
\mathrm{Y}=\alpha+b_{1} x_{1}+b_{2} x_{2}+\text { e............. } \\
\text { Keterangan: } \\
\mathrm{Y} \quad=\text { Audit Report Lag } \\
\alpha \quad=\text { Konstanta } \\
b_{1}-b_{2}=\text { Koefisien regresi }
\end{gathered}
$$




$$
\begin{array}{ll}
x_{1} & =\text { Ukuran Perusahaan } \\
x_{2} & =\text { Umur Perusahaan } \\
\mathrm{e} & =\text { Error }
\end{array}
$$

\section{b. Moderated Regression Analysis} (MRA)Uji interaksi merupakan salah satu cara yang digunakan dalam menguji apakah suatu variabel merupakan variabel moderating. Uji interaksi antar variabel disebut dengan Moderated Regression Analysis (MRA) yang merupakan aplikasi khusus linier berganda dimana dalam persamaan regresinya mengandung unsur interaksi yang dilakukan dengan perkalian dua atau lebih variabel independen (Ghazali, 2012:198).

$$
\begin{aligned}
& \mathrm{Y}=\alpha+b_{1} x_{1}+b_{2} x_{2}+b_{3} z_{1} b_{4} x_{1} \cdot z_{1}+b_{5} \\
& x_{2} \cdot z_{1}+\mathrm{e} \ldots \ldots \ldots \ldots \ldots . .(2) \\
& \mathrm{Y}=\alpha+b_{1} x_{1}+b_{2} x_{2}+b_{3} z_{2} b_{4} x_{1} \cdot z_{1}+b_{5} \\
& x_{2} \cdot z_{1}+\mathrm{e} \ldots \ldots \ldots \ldots . . .(3)
\end{aligned}
$$

Keterangan:

$$
\begin{aligned}
& \mathrm{Y}=\text { Audit Report Lag } \\
& \mathrm{A} \quad=\text { Konstanta } \\
& b_{1}-b_{4}=\text { Koefisien regresi } \\
& x_{1} \quad=\text { Ukuran Perusahaan } \\
& x_{2}=\text { Umur Perusahaan } \\
& \mathrm{z}_{1}=\text { Profitabilitas } \\
& \mathrm{z}_{2}=\text { Solvabilitas } \\
& \mathrm{e} \quad=\text { Error }
\end{aligned}
$$

\section{HASIL DAN PEMBAHASAN}

Dengan mengeliminasi sesuai dengan kriteria yang telah ditetapkan sehingga pada proses akhir terdapat 214 perusahaan manufaktur yang terdaftar di Bursa Efek Indonesia selama kurun waktu 2015-2016 yang dijadikan sampel dalam penelitian ini.
Tabel 4.1

\begin{tabular}{lrrrrr}
\multicolumn{5}{c}{ Hasil statistik deskriptif } \\
\hline & $\mathrm{N}$ & Minimum & Maximum & \multicolumn{1}{c}{ Mean } & Std. Deviation \\
\hline$x_{1}$ & 214 & 10,60 & 19,38 & 14,4038 & 1,58261 \\
$x_{2}$ & 214 & 6,00 & 103,00 & 38,8972 & 16,32961 \\
$z_{l}$ & 214 & $-0,55$ & 9,59 & 0,0823 & 0,66103 \\
$z_{2}$ & 214 & $-225,23$ & 44,44 &, 1917 & 15,85190 \\
ARL & 214 & 41,00 & 349,00 & 81,4299 & 25,89292 \\
Valid N & 214 & & & & \\
(listwise) & 214 & & & & \\
\hline
\end{tabular}

Hasil statistik deskriptif pada tabel 4.1 menunjukkan dari tahun 2015-2016 audit report lag mempunyai nilai minimum sebesar 41,00 dan nilai maksimum sebesar 349,00. Adapun rata-rata audit report lag adalah 81,4299 dengan standar deviasi sebesar 25,89292. Hal ini mengindikasikan perusahaan yang dijadikan smpel dalam penlitian ini rata-rata menyampaikan laporan keuangannya secara tepat waktu dibawah standar hari yang disyaratkan oleh OJK.

Pada hasil perhitungan statistik deskriptif ukuran dan umur perusahaan mempunyai nilai minimum 10,60 dan 6,00. Adapun rata-rata nilai ukuran dan umur perusahaan adalah 14,4038 dan 38,972 dengan standar deviasi sebesar 1,58261 dan 16,3. Hal ini mengindikasikan perusahaan yang dijadikan smpel dalam penlitian ini rata-rata mempunyai aset senilai diatas 10 trilyun rupiah atau dapat dikatakan sebagai perusahaan lapis dua. Sedangkan umur

Profitabilitas memiliki nilai mean sebesar 0,0823 dan standart deviation sebesar 0,66103 . Pada hasil perhitungan statistik deskriptif rasio solvabilitas Adapun rata-rata nilai solvabilitas adalah 0,1917 dengan standar deviasi sebesar15,85190.

\section{Pengujian Hipotesis}

Tabel 4.2

Hasil Uji Regresi Linear Berganda Persamaan 1

\begin{tabular}{lrrrl}
\hline Variabel & & & & \\
Independen & Koef. Reg & \multicolumn{1}{c}{$\mathrm{t}$} & \multicolumn{1}{c}{ Sig. } & Keterangan \\
\hline 1 (Constant) & 128,738 & 8,096 & 0,000 & \\
$x_{1}$ & $-2,831$ & -1.508 & 0,015 & Signifikan \\
$x_{2}$ & -.168 & -2.464 & 0,133 & Tidak Signifikan \\
F hitung & 5,799 & & & \\
p-value & 0,004 & & & \\
Adjusted $\mathrm{R}^{2}$ & 0,043 & & & \\
\hline
\end{tabular}


Berdasarkan tabel 4.2 menujukkan hasil uji regresi dengan nilai adjusted $R^{2}$ sebesar 0,043 atau $4,3 \%$. Hal ini menunjukan $4,3 \%$ audit report lag dapat dijelaskan oleh variabel ukuran perusahaan dan umur perusahaan . Sedangkan 95,7\% dijelaskan oleh faktor lain diluar model penelitian.

Hipotesis pertama menyatakan bahwa ukuran perusahaan berpengaruh terhadap audit report lag. Hasil pengujian ukuran perusahaan berpengaruh terhadap audit report lag menunjukkan tanda koefisien negatif dengan $p$ value dari t hitung -1.508 dengan tingkat signifikansi sebesar 0,015 . Secara statistik nilai ini signifikan pada tingkat $\alpha=5 \%$ sehingga dapat disimpulkan hipotesis pertama diterima.

Hasil penelitian ini sejalan dengan penelitian yang dilakukan oleh [6], [10], [11], [12], [13] yang menyatakan bahwa ukuran perusahaan berpengaruh signifikan terhadap audit report lag. Namun bertentangan dengan penilitian [15], [16] yang menyatakan ukuran perusahaan tidak berpengaruh terhadap audit report lag.

[11] menemukan bahwa ukuran klien memiliki dampak langsung pada pekerjaan auditor, dan waktu yang dihabiskan dalam proses audit karena perusahaan yang relatif besar memiliki transaksi yang lebih besar dibanding dengan perusahaan yang relatif kecil. Namun demikian perusahaan besar juga memiliki kewajiban moral untuk menjaga reputasi perusahaan di mata investor dan pihak-pihak yang berkepentingan terhadap laporan keuangan yang dikeluarkan oleh perusahaan, sehingga wajib bagi perusahaan besar untuk menampilkan laporan keuangan yang baik dan tepat waktu [22].

Dalam hasil penelitian ini perusahaan besar cenderung memiliki waktu audit report lag lebih pendek. Hal ini dapat memungkinkan karena perusahaan yang lebih besar pada umumnya memiliki lebih banyak sumber daya, proses akuntansi dan proses pengendalian internal yang lebih baik sehingga memudahkan auditor dalam menyelesaikan audit secara tepat waktu karena minimnya kesalahan dalam penyajian laporan keuangan yang dilakukan oleh perusahaan besar [10].
Pengujian hipotesis kedua $\left(\mathrm{H}_{2}\right)$ pada hasil uji t diperoleh nilai $t_{\text {hitung }}$ sebesar -1,450 dengan tingkat signifikansi 0,148>0,05. Hal ini menunjukkan bahwa $\mathrm{H}_{2}$ ditolak. Dengan demikian berarti bahwa umur perusahaan tidak berpengaruh terhadap audit report lag.

Ketepatwaktuan penyampaian laporan keuangan menjadi hal sangat diperhatikan baik oleh persahaan baru maupun perusahaan yang lama. Menurut [23] baik perusahaan baru maupun perusahaan yang sudah lama berdiri akan berusaha untuk segera menyelesaikan proses audit karena mereka diawasi secara ketat oleh para investor, pemerintah, dan lembaga lainnya.

Perusahaan yang baru berdiri untuk dapat menarik perhatian investor ialah melalui laporan kinerja mereka, yaitu laporan keuangan. Sementara, perusahaan yang sudah lama beroperasi akan berupaya agar laporan keuangan dapat dipublikasikan secara tepat waktu guna mempertahankan kepercayaan para investor yang telah dimiliki sejak lama. Sehingga dapat disimpulkan bahwa lamanya waktu atau umur perusahaan tidak mempengaruhi lamanya audit report lag.

Hasil penelitian ini sejalan dengan penelitian yang dilakukan oleh [13]. Namun hasil ini tidak sejalan dengan penelitian yang dilakukan oleh [6], [11], [12], [17], [18] yang menunjukkan bahwa umur perusahaan berpengaruh signifikan terhadap audit report lag.

Tabel 4.3

Hasil Uji Regresi Linear Berganda Persamaan 2

\begin{tabular}{|c|c|c|c|c|}
\hline $\begin{array}{l}\text { Variabel } \\
\text { Independen } \\
1 \text { (Constant) }\end{array}$ & $\begin{array}{r}\text { Koef. Reg } \\
136,871\end{array}$ & $\begin{array}{c}\mathrm{t} \\
8,066\end{array}$ & ${ }_{0}^{\text {Sig. }}$ & Keterangan \\
\hline$x_{1}$ & $-3,435$ & $-2,733$ & 0,007 & Signifikan \\
\hline$x_{2}$ & -.168 & $-1,127$ & 0,261 & Tidak Signifikan \\
\hline$z_{1}$ & $-220,353$ & $-1,388$ & 0,167 & Tidak Signifikan \\
\hline$x_{1}, z_{1}$ & 15,004 & 1,287 & 0,199 & Tidak Signifikan \\
\hline$x_{2} z_{1}$ & $-0,110$ & $-0,136$ & 0,892 & Tidak Signifikan \\
\hline F hitung & 2,798 & & & \\
\hline p-value & 0,018 & & & \\
\hline Adjusted $\mathrm{R}^{2}$ & 0,063 & & & \\
\hline
\end{tabular}

Berdasarkan tabel 4.3 menujukkan hasil uji regresi dengan nilai adjusted $R^{2}$ sebesar 0,063 atau 
6,3\%. Hal ini menunjukan $6,3 \%$ audit report lag dapat dijelaskan oleh variabel ukuran perusahaan dan umur perusahaan . Sedangkan 93,7 \% dijelaskan oleh faktor lain diluar model penelitian.

Nilai signifikansi pada hasil uji t sebesar 0,199 $>0,05$ sehingga $\mathrm{H}_{3}$ ditolak. Hal ini memiliki arti bahwa profitabilitas tidak mampu memoderasi pengaruh ukuran perusahaan terhadap audit report lag dan untuk hipotesis 4 nilai signifikansi pada hasil uji t sebesar $0,892>0,05$ sehingga $\mathrm{H}_{4}$ ditolak yang memiliki arti bahwa profitabilitas tidak mampu memoderasi pengaruh umur perusahaan terhadap audit report lag.

Hasil penelitian ini bertentangan dengan [24] yang menyatakan bahwa profitabilitas mampu memoderasi pengaruh ukuran perusahaan terhadap audit report lag.

Baik perusahaan yang berskala kecil maupun besar dan mempunyai umur perusahaan yang sudah lama tidak dapat dijadikan acuan bahwa perusahaan tersebut mampu menyajikan laporan keuangan secara tepat waktu dan memiliki tingkat profitabilitas yang tinggi, perusahaan yang sudah go public akan melaporkan kinerja perusahaannya sesegera mungkin kepada publik tanpa mempertimbangkan apakah kinerja perusahaan tersebut akan menjadi "good news" maupun "bad news" hal ini dikarenakan regulasi yang diterapkan di Indonesia mengharuskan perusahaan untuk melaporkan laporan keuangan secara tepat waktu kepada publik dan akan diberikan sanksi yang berat ketika perusahaan melanggar regulasi tersebut.

Tabel 4.4

Hasil Uji Regresi Linear Berganda Persamaan 3

\begin{tabular}{lrrrl}
\hline Variabel & & & & \\
Independen & Koef. Reg & $\mathrm{t}$ & Sig. & Keterangan \\
1 (Constant) & 132,001 & 7,729 &, 000 & \\
\hline$x_{1}$ & $-3,086$ & $-2,389$ &, 018 & Signifikan \\
$x_{2}$ &,- 173 & $-1,450$ &, 148 & Tidak Signifikan \\
$z_{2}$ & $-2,960$ &,- 441 &, 660 & Tidak Signifikan \\
$x_{I .} z_{2}$ &, 249 &, 440 &, 660 & Tidak Signifikan \\
$x_{2 .} z_{2}$ &,- 002 &,- 101 &, 920 & Tidak Signifikan \\
F hitung & $\underline{2,498}$ & & & \\
$p$-value & 0,032 & & & \\
Adjusted $\mathrm{R}^{2}$ & 0,057 & & & \\
\hline
\end{tabular}

Berdasarkan tabel 4.4 menujukkan hasil uji regresi dengan nilai adjusted $R^{2}$ sebesar 0,057 atau $5,7 \%$. Hal ini menunjukan $5,7 \%$ audit report lag dapat dijelaskan oleh variabel ukuran perusahaan dan umur perusahaan . Sedangkan 94,3\% dijelaskan oleh faktor lain diluar model penelitian.

Nilai F yang diperoleh sebesar 2,498 dengan nilai signifikansi 0,032. Nilai signifikansi diatas lebih kecil dari nilai taraf signifikansi 0,05. Sehingga dapat disimpulkan bahwa secara bersama-sama variabel ukuran perusahaan dan umur perusahaan dengan solvabilitas sebagai variabel moderating mempengaruhi audit report lag, hasil ini juga menggambarkan bahwa model regresi yang digunakan dalam penelitian ini fit.

Pengujian hipotesis kelima $\left(\mathrm{H}_{5}\right)$ pada hasil uji $\mathrm{t}$ diperoleh nilait hitung $_{\text {gebsar }}$, 440 dengan tingkat signifikansi 0,660 > 0,05 dan nilai $t_{\text {hitung }}$ sebesar 0,101 dengan tingkat signifikansi $0,920>0,05$ untuk pengujian hipotesis keenam

$\left(\mathrm{H}_{6}\right)$. Hal ini menunjukkan bahwa $\mathrm{H}_{5}$ dan $\mathrm{H}_{6}$ ditolak. Dengan demikian berarti bahwa solvabilitas tidak mampu memoderasi hubungan antara ukuran perusahaan dan umur perusahaan dengan audit report lag.

Keberadaan variable solvabilitas yang dipahami sebagai variabel moderating dalam penelitian ini tidak terbukti memperlemah ataupun memperkuat pengaruh ukuran perusahaan dan umur perusahaan pada audit report lag. Penelitian ini menunjukkan bahwa besar kecilnya ukuran maupun lama pendeknya umur suatu perusahaan yang memiliki tingkat solvabilitas yang tinggi ataupun rendah bukan menjadi jaminan yang dapat mempersingkat audit report lag.

\section{SIMPULAN}

Laporan keuangan auditan sebagai sumber informasi akuntansi yang dapat diandalkan harus dipublikasikan sesegera mungkin untuk menjamin ketersediaan informasi yang digunakan oleh pihak yang berkepentingan dalam pengambilan keputusan. Dengan demikian, menurunkan rentang waktu penyelesaian laporan audit menjadi faktor yang sangat krusial bagi pengguna laporan keuangan auditan.

Dengan menambahkan variabel profitabilitas dan solvabilitas sebagai variable moderating untuk 
menguji apakah kedua variable moderating tersebut dapat memperlemah ataupun memperkuat pengaruh ukuran perusahaan dan umur perusahaan pada audit report lag, maka penelitian ini menemukan bukti secara empiris bahwa (i) ukuran perusahaan berpengaruh negatif dan signifikan terhadap audit report lag, (ii) umur perusahaan tidak berpengaruh terhadap audit report lag, (iii) profitabilitas tidak mampu memoderasi pengaruh ukuran perusahaan terhadap audit report lag, (iv) profitabilitas tidak mampu memoderasi pengaruh umur perusahaan terhadap audit report lag, (v) solvabilitas tidak mampu memoderasi pengaruh ukuran perusahaan terhadap audit report lag, (iv) solvabilitas tidak mampu memoderasi pengaruh umur perusahaan terhadap audit report lag.

Penelitian ini memberikan implikasi bahwa untuk kasus di Indonesia sendiri umur perusahaan tidak menjadi faktor krusial yang menyebabkan keterlambatan penyampaian laporan keuangan kepada publik. Namun harus diperhatikan masih banyak variable yang belum diteiliti dalam penelitian ini yang dapat menyebabkan keterlambatan penyampaian laporan keuangan oleh suatu perusahaan, seperti perubahan regulasi standar akuntansi keuangan.

\section{REFERENSI}

[1] Dewi, Ni Luh Nyoman Adi Kusuma dan Wiratmaja dan I Dewa Nyoman Wiratmaja. 2016. Likuiditas Sebagai Pemoderasi Pengaruh Ukuran Perusahaan Pada Audit Report Lag. E-Jurnal Akuntansi Universitas Udayana. Vol.15, No.3.

[2] Situmorang, M.S., 2011. " Transisi Menuju Ifrs Dan Dampaknya Terhadap Laporan Keuangan (Studi Empiris Pada Perusahaan Yang Listing Di Bei)”. Skripsi. Universitas Dipnegoro. Semarang.

[3] Diehl, Kevin A. 2010. The Real Cost of IFRS: The Relationship between IFRS Implementation and Audit, Tax, and Other Auditor Fees. International Research Journal of Finance and Economics.

[4] Abdulla, J.M.A (1996). Timelines of Bahraini annual reports, In Doupnik T.S. and Salter, S.B.
(Eds.), Advancesin Internastional Accounting, 9:73-88)

[5] Suwardjono, 2005. "Teori Akuntansi: Perekayasaan Pelaporan Keuangan”. Edisi Ketiga. Jakarta: Salemba Empat.

[6] Dewangga, Arga dan Herry Laksito. 2015. Faktor-Faktor Yang Berpengaruh Terhadap Audit Report Lag. Diponegoro Journal Of Accounting. Vol.4, No.3.

[7] Sulistyo, Adhy Noor. 2010. Analisi Faktor- Faktor Yang Berpengaruh Terhadap Ketepatan Waktu Penyampaian Laporan Keuangan Pada Perusahaan Yang Listing di Bursa Efek Indonesia Periode 2006. Skripsi. Universitas Diponegoro.

[8] Fiedler. F.E. (1967). A Theory of Leadership Effectiveness. New York. McGraw-Hill.

[9] Amani, Fauziyah Althaf. 2016. Pengaruh Ukuran Perusahaan, Profitabilitas, Opini Audit, dan Umur Perusahaan Terhadap Audit Delay. Jurnal Nominal. Vol.5, No.1.

[10]Eighlaiow, Salem et al. 2012. A Review of The Empirical Determinants of Audit Delay. Corporate Ownership and Control. Vol 9.

[11] Yaacob, N.M and Che-Ahmad, A., 2011. "IFRS Adoption and Audit Timeliness: Evidence from Malaysia". The Journal of American Academy of Business, Cambridge * Vol. 17 *.

[12] Togasima, Christian Noverta dan Yulius Jogi Christiawan. 2014. Analisis Faktor-Faktor Yang Mempengaruhi Audit Report Lag Pada Perusahaan Yang Terdaftar di Bursa Efek Indonesia Pada Tahun 2012. Business Accounting Review. Vol.2, No.2.

[13]Azhari, Muhammad et al. 2014. Faktor-Faktor Yang Mempengaruhi Audit Delay (Studi Kasus Pada Perusahaan Perbankan Yang Terdaftar di Bursa Efek Indonesia). Jurnal Ilmu \& Riset Akuntansi. Vol.3, No.10.

[14]Amariyah, Siti et al. 2017. Pengaruh Profitabilitas, Solvabilitas dan Umur Perusahaan Terhadap Audit Report Lag Pada Perusahaan 
Manufaktur Yang Terdaftar di Bursa Efek Indonesia Periode 2013-2015. Jurnal Ekonomi Akuntansi. Vol.3.

[15] Ayemere, IbadiN Lawrence and Elijah, Afensimi. 2015. Corporate Attributes and Audit Delay in Emerging Markets: Empirical Evidence from Nigeria. International Journal of Business and Social Research, Vol 5.

[16] Vuko, Tina dan Cular, Marko. 2014. Finding Determinants of Audit Delay by Pooled OLS Regression Analysis. Croatian Operational Research Review (CORR 5).

[17] Suginam. 2016. Faktor-Faktor Yang Mempengaruhi Audit Report Lag Pada Perusahaan Sektor Perdagangan Jasa dan Investasi Yang Terdaftar di Bursa Efek indonesia. ISSN. Vol.XI, No.1.

[18] Widhiasari, Ni Made Shinta dan I Ketut Budiartha. 2016. Pengaruh Umur Perusahaan, Ukuran Perusahaan, Reputasi Auditor, dan Pergantian Auditor Terhadap Audit Report Lag. E-Jurnal Akuntansi Universitas Udayana. Vol.15, No.1.

[19] Mazkiyani, Nur dan Handoyo, Sigit. 2017. Audit Report Lag of Listed Companies In Indonesia Stock Exchange. Jurnal Aplikasi Bisnis. Vol. 17 No.1.

[20]Kartika, Andi. 2011. Faktor-Faktor Yang Mempengaruhi Audit Delay Perusahaan Manufaktur Yang Terdaftar di BEI. ISSN. Vol.3, No.2.

[21] Karami, Najaf dan Mohammadvand, Zhila. 2016. The Relationship Among Financial and NonFinancial Characteistics and Duration of Implementation and completion of the Audit of Listed companies In Tehran Stock Exchange. European Journal of Economic and Finacial Reseach. Volume 1.

[22] Pramaharjan, Brian dan Nur Cahyonowati. 2015. Faktor-Faktor Yang Berpengaruh Terhadap Audit Report Lag Pada Perusahaan Manufaktur. Diponegoro Journal Of Accounting. Vol.4, No.4.
[23]Charviena dan Elisa Tjhoa. 2016. Pengaruh Ukuran Perusahaan, Laba Rugi Operasi, Solvabilitas, Umur Perusahaan, Klasifikasi Industri, dan Ukuran KAP Terhadap Audit Delay. Ultima Accounting. Vol.8, No.2

[24]Zebriyanti, Devi Eka dan Anang Subardjo. 2016. Faktor-Faktor Yang Berpengaruh Terhadap Audit Delay Pada Perusahaan Perbankan. Jurnal Ilmu dan Riset Akuntansi. Vol.5, No.1. 